\title{
Una investigación de los delitos cibernéticos desde el punto de vista de la jurisprudencia de Imamieh (Irán)
}

\section{An Investigation of Cyber Crimes from the Point of View in Imamieh (Iran) Jurisprudence}

\author{
Fatemeh Vahedi Kabiri ${ }^{1}$, Mostafa Rajaipour ${ }^{2 a}$, Seyed Mohsen Razmi ${ }^{3}$ \\ Islamic Azad University, Mashhad, Iran ${ }^{123}$ \\ Orcid ID: https://orcid.org/0000-0003-4547-8115 \\ D Orcid ID: https://orcid.org/0000-0002-2289-0070² \\ iD Orcid ID: https://orcid.org/0000-0002-3853-5348
}

Recibido: 12 de mayo de 2020

Aceptado: 04 de octubre de 2020

\begin{abstract}
Resumen
El objetivo de este estudio fue una investigación de los delitos cibernéticos desde el punto de vista de la jurisprudencia de Imamieh (Irán). El presente estudio es una investigación descriptivoanalítica. La importancia del tema ha obligado al autor no solo a revisar las ideas de los académicos, sino también a brindar una base de reconocimiento para los delitos cibernéticos. Los resultados muestran que los juristas creen que los actos que conllevan la depravación deben perseguirse mediante el castigo; y en algunos casos lo han condenado como mofsed-e-filarz, que se castiga con la muerte. Asimismo, se han investigado los puntos de vista de los juristas; la investigación se ha basado en las investigaciones. A través de las investigaciones realizadas, se deja en claro que ciertos delitos que han utilizado las redes sociales para disminuir la castidad en la sociedad incluyen la divulgación de adulterio, proxenetismo, pornografía, etc., que han sido referidos por los legisladores y los santos imanes y el Profeta. En el primer paso, estos delitos no solo son contra el delincuente, sino que también apuntan y debilitan las bases de las unidades más importantes de toda sociedad, que son las familias.
\end{abstract}

Palabras clave: Ciberespacio, adulterio, ciberdelitos, internet, jurisprudencia

\begin{abstract}
The aim of this study was an investigation of cybercrime from the point of view of Imamieh (Iran) jurisprudence. The present study is a descriptive-analytical investigation. The importance of the topic has forced the author not only to review the ideas of academics, but also to provide a
\end{abstract}

a Corresponding Author: E-mail: mostafarajae@yahoo.com 
foundation of recognition for cybercrime. The results show that jurists believe that acts of depravity should be prosecuted through punishment; and in some cases they have condemned it as mofsed-e-filarz, which is punishable by death. Likewise, the points of view of jurists have been investigated; research has been based on research. Through the investigations carried out, it is made clear that certain crimes that have been used by social networks to decrease chastity in society include the disclosure of adultery, pimping, pornography, etc., which have been referred to by legislators and saints imams and the Prophet. . In the first step, these crimes are not only against the offender, but also target and weaken the foundations of the most important units of any society, which are families.

Keywords: Cyberspace, adultery, cybercrimes, internet, jurisprudence

\section{Introduction}

The current era, is the era of communication and reign of media over human's lives. The obscure civilization of the west has tried to establish thousands of communication networks in order to propagate secularism (Bastani, 2018). These media broadcast programs with this aim; and so, it must be taken into the account that when we talk about the satellite and other cyberspaces, the first things to catch the attention are anti-cultural issues, with the scientific and political issues ranking next (Keshavarzi, 2014). All these networks, with all their different objectives and tastes, are similar in terms of attacking religious basics, and each of them are opposing Islam with a certain objective. Though this attack has started silently, it aims the belief basics of people and covers the entire groups with a delicate accuracy (Saffari, 2001).

Social networks on the internet have evolved the manners of communication and have also born several evolutions in every aspect and level of human lives; and considering these changes, it can be dangerous as much as it can by beneficial (Bai, 2016). The new crimes are amongst those destructive effects of the social media, which are totally different than traditional crimes in terms of characteristics, and require evolutions in the laws of countries to be dealt with. In Islamic countries, jurisprudence is the basis of laws, and so it must be able to respond to the new evolutions as well (Bastani, 2018).

Jurisprudential investigation of certain frequently repetitive crimes in the cyber space which have evolved into highly complex forms with the evolutions in communications has also been considered by this study (Noorbahar, 1990).With the expansion of the cyberspace and applications of IT in people's everyday lives, some new forms of crimes and abuses have been emerged, which are known as cybercrimes. Due to increase in the number of users of cyberspaces, 
every day, new types of cybercrimes emerge, facing law and jurisprudence researchers with numerous questions.

The purpose of the present study was to investigate cyber-crimes from the point of view of Imamieh jurists. Using social networks in the cyberspace, has no history of being ruled by the sentences of Islam, and considering the jurisprudential basics, the sanctity and legitimacy of using the cyberspace have been investigated in the present study.

\section{The History of Cyber Crimes}

\section{Theoretical schemes of the study}

Due to global advances in computers, close international cooperation regarding data processing, and increasing flow of international data, cybercrimes have attracted international attentions during the past few years. It has been concluded that fighting cybercrimes is not currently in an efficient level; rather the fight must be conducted under the light of close international cooperation, especially in the field of criminology, and clarification and amendment of legal regulations, and adoption of adequate security measures for prosecution of cybercrimes. To this end, the researchers in this field have conducted various investigations and studies, which can be categorized as domestic and foreign efforts (Keshavarzi, 2014, 399).

In terms of foreign references, investigating the rules and laws envisaged for cybercrimes with respect to the criminal procedures of developed countries, shows that initially and during the 1970s, these countries were reacting to cybercrimes targeting privacy; however, they subsequently started to amend the laws and regulations relating to economic crimes, while focusing the domain of cybercrimes on intellectual property (ShahidSaani, 2009, 399).

Among the research efforts in the international scene, one can refer to the activities of the organization of collaboration and economic development; and also in order to gain more insight regarding the legal aspects of information technology, one may refer to the article of "actions of regional and international organizations, concerning cybercrimes” written by BatoolPakzad (Bastani, 2018, 112).

\section{Cyber Space}

The term "cyberspace" is comprised of the words "Cyber" and "Space". In terms of vocabulary, space is defined as an extensive free, empty and accessible area. In addition, the word Cyber or Virtual is used to refer to computers, and computer networks in specific. So in an 
expressional manner it can be stated that by "cyberspace” it is referred to an imaginary, nonsubstantial domain or territory of interactive mass communications facilitated by computers connected in a digital context (Mohammad, 2004). By cyber or virtual, we here refer to any communication facilitated by a tool/apparatus. This communication can take place through mail, over telephone or through chatting on the internet and social media.

\section{Jurisprudential Basics of the Cyberspace}

Since there are almost no records of cyberspace in the domain of jurisprudence, in order to explain and discuss cybercrimes, we must elaborate on the jurisprudential references concerning depravity, as well as the holy verses and narratives relating to it. Although certain crimes against ethics and public chastity have found their ways into the cyberspace with the emergence and expansion of the internet (pornography, sex tourism, adultery, pandering, and etc.); still not all of these crimes can be fitted into the framework of cybercrimes, since in for some cases the legislator has not applied criminalization.

In fact, in these crimes, the criminals use computers as tools/apparatuses and facilitate their actions. Amongst the counts in this field generally criminalized by Iran's criminal legislator it can be referred to pandering and pornography. Domains such as producing, publishing, dealing and, trading pornographic visuals, making accusations and publishing false information, inviting individuals to perform criminal acts against ethics on the cyberspace, propagating depravity, teaching criminal acts and, facilitating adultery are subsets of pandering and pornography (Ameli, 2008). these are in fact the main elements targeted by filtering.

\section{Pandering}

The second crime to count as a cybercrime, would be pandering, which is also considered as a great sin, pointed to in the domain of Islamic punishment, set to be followed by a certain punishment. According to the definition/description provided for pandering in the book of “Lomeh”, pandering is defined as facilitation of adultery including sodomy and lesbian-relations amongst two individuals (Al-Khasal, 1990). Also gathering, or connecting two prostitutes is considered as pandering (Bai, 2016). In addition, in Javaherkalam we read: pandering is to gather men and women for adultery, or just men for sodomy; whether being children (Fallah, 2008).

What is concluded from this argument is that the levels of offence vary for those who intentionally commit it, and those one of whom deceives the other(s) into it; so the legislator must 
have had differentiated between the punishments considered for the former and latter groups. Yet the other gap evident in the law of cybercrimes is that no pointing has been made to occurrence of adultery through computers. This is while offenders are able to use computers and the internet to establish unhealthy and illegitimate relations even with people half-way across the globe. However, the legislator might have wanted this offence to be investigated from the lens of traditional laws, irrespective of the type of the tool involved. Such perception seems okay, since the quality of adultery mediated through computers cannot exceed its limits in traditional senses, and so the offence can be evaluated using the same old law.

\section{Pornography}

The third type of cybercrimes includes pornography, which is considered as one of the most important offences against public ethics and chastity, leaving direct effects on the families. In general senses, pornography means content created or published for sexual arousal. Images of male and female genitals, sex between men and women, women and women, and etc. are considered as pornography instances, and criminal acts relating to them include displaying, providing, producing, trading and creating vulgar content (Muhaddith, 1990, 129). Emergence of the Internet has transformed this type of crime from its traditional type to a modern tool for sex abusers. This modern communicational technology has increased the volume of recorded abuses, and there are two different views regarding it: one relates to the publication of the noisy issue of Pine Computer. This case is viewed as the commencing of paying attention to the issue of child pornography on the cyberspace; however, the court did not find the website guilty and stated that the offence puts the Internet Providers' under prosecution, but still the issue of pornography was the subject of the case. As other important cases in this regard, it can be pointed to the issue of Wonderland Club and the Orchid Club case, along with a bunch of other important cases that were brought to courts in 1998 and 1999. In any sense, the late 90s were the time when attention was paid to child pornography (Khorasani, 2002, 129).

\section{Crime of the Doer of Haram in the View of Jurisprudence}

According to the mutual agreement between the jurists, anyone who commits a haram act or refuses to do an obligated act, deserves criminal punishment. According to this introduction, if it is proved that pornography is a haram act, according to the mutual agreement between jurists, it is acceptable in Sharia to consider criminal punishments for the offenders. For the other hand, the 
haram-ness of pornography, which includes displaying still or dynamic vulgar images, it can be pointed to certain offences such as haram-ness of publication and propagation of adultery, haramness of disclosure of secrets, and participation in sinning.

\section{Participation in Sinning}

Publishing videos and images with vulgar content causes others to be trapped by sins and corruption; and, therefore, doing so is considered as participation in sinful deeds; also as clarified by the holy verse of it is considered as a haram act, and as the mutual agreement between the jurists holds, the committer may be punished by criminal laws.

In addition, publishing people's images in some cases allows certain individuals to misuse the images and use them for sexual harassment of the subjects; and therefore, it is considered to being an introduction to a haram deed. Some jurists believe that such deeds are self-related haram, while others view them as others-related haram (Khorasani, 2002); this is while some others believe that such acts are functions of realizing the introductory acts (Makarem-Shirazi, 1995; Najafi, 1989). Since pornography requires images to facilitate sexual harassment or haram deeds such as lustfully looking at others, so it can be considered as an instance of the mentioned type.

Sometimes, the introductory act to a haram deed is not caused by the promoting tools. In these cases, if the intention of the doer of the introductory act to the haram deed was to result in a haram deed externally, and the haram deed has been done, the doer of the introductory act has also committed a haram act; however, if the haram deed is not externally realized, the doer of the introductory act to a haram deed, has not done a haram act; unless there is a basis that considers the immediate case as hara'm (Khorasani, 2002, 361). On this basis, if the intention of the committer of the pornographic act is to make others commit sins through lustful acts and the intention is realized, according to certain principal basics, pornography can be considered as a haram act.

\section{Results and discussion}

\section{Disclosure of Secrets}

Some instances of pornography are somehow related to private videos and images of legitimate sexual relationships, and these instances are covered by the issue of haram-ness of disclosure of secrets; even in case of displaying images and videos of sexual relationships captured 
secretly; irrespective of whether they are legitimate or illegitimate, which are considered as instances of disclosure of secrets; a haram act indeed.

Some instances of pornography are titled as other haram acts such as malversation; since showing other people's images without their consent causes harms to them, sometimes causes in collapse of families or deaths. There are multiple instances in which people have published others' images with different intentions, and have caused confusion for the victims. In some cases, where the acts of pornography are extensive, the committers can be punished for being a Mofsid-Filarz (Makarem Shirazi, 1995).

In addition, with respect to sentences of certain jurists (Haji, 2001), since stating the sexual conditions of individuals is haram, some instances of pornography can decisively be included as haram deeds; because when stating the beauties or sexual conditions of faithful women is haram, showing their images also will be considered as haram. Still, it seems that the main reason why stating faithful women's sexual conditions and beauties is haram, relates to one of the previously mentioned witnesses (Al-Khasal, 1990, 64). On this basis, the haram-ness of the act of Tashbib (stating faithful women's sexual conditions or beauties) is independently a sufficient reason.

The other point is that pornography could also be banned in other ways as well. For instance, displaying edited and fake images of people having sexual relationship, or people standing by stranger men or women is also undesirable and illegitimate since false attribution of an illegitimate action to someone is haram.

\section{Privacy in the Cyberspace}

The main axis of preserving privacy in the cyberspace is focused on definitions referring to individuals' control over their data. People in a society have information, which they tend to keep secret and do not want others to know about them. When such information is related to the privacy of people, are considered as individuals' privacy, and when such information is published on the web, the issue of privacy in the cyberspace is brought up.

\section{Jurisprudential Components Generalizable to the Cyberspace}

Among the seven-fold components pointed to in order to safeguard privacy, although all can somehow be related to safeguarding privacy in the cyberspace, three components have been referred to more than others. These components include: prohibition of investigation and spying; 
prohibition of propagation of prostitution; and, prohibition of eavesdropping. In the following, the mentioned components will be discussed in details (Ismaili, 2016).

\section{Prohibition of Investigating and Spying}

Different definitions have been proposed for investigating and spying. The normalized type of investigating is known as greeting and includes asking people about their good and bad deeds. However, if one asks questions about the secret affairs, or asks about obvious or good deeds but for bad intentions, he/she is investigating. In Persian, investigating means to seek news, and in terms of vocabulary, the scholars have defined it as follows: it refers to investigating individuals’ secret affairs to discover the flaws and darkness of their lives (Mir Khalili, 2001).

When people investigate others' lives to find out their flaws, they are actually intervening with their affairs, and this can lead to violation of their privacy. In this verse, the God forbids people from investigating in the lives and affairs of believers; also since the word «Don't explore» has not been stated, it can be inferred that investigating and spying in others' lives and affairs are generally haram, unless excused especially.

Both Shia and Sunni hadiths have forbidden and criminalized investigating others’ lives. In the books of "Sahih Bokhari" and "Muslim", Abuharireh has been quoted that the Holy Prophet says: do not investigate and spy in people’s obvious and secret affairs, and do not disclose information regarding each other (Ismaili, 2016).

It has also been stated: avoid spying and investigating on the secrets of believers, because whoever investigates others' flaws, will be investigated by god for their flaws, and anyone in whose affairs the god investigates his/her flaws, will be dishonored; even if the flaw had taken place in the privacy of their homes (Makarem, 1995, 104). In addition, also Imam Sadeq (Rey Ghodsi, 2010, 392).

Adding together the personal data uploaded to social media, and the needs to investigate these data provides the necessary contexts for investigation in individuals’ private affairs, which is in fact a violation of the privacy. The subject of the sentence of prohibition of investigating and spying, is the nature of individuals' personal data, and because of this prohibition, the legislator has tried to define a limit to maintain the privacy of such data. In other words, the attention of the legislator was focused on supporting privacy, and it is tried to keep the information inaccessible to others. It is the individuals' data for which privacy must be considered. Considering this info, it can be concluded that the sentence of prohibition of investigating and spying in others' lives and 
affairs is not merely limited to the real world; rather, the issue must be accepted as one also covering the cyberspace. Ultimately it must be stated that not only real-world aspects, but also this prohibition covers aspects of life in the cyberspace as well.

\section{Prohibition of Propagation of Prostitution}

The Quran introduces propagation of prostitution as an act followed by both worldly and after-worldly torments. The verse 19 of sura of Noor. This means that those who enjoy to propagate inappropriate and forbidden acts among the believers, will be faced with great torment both in this world and in the afterlife; God knows this and you don't. on this basis, in Islamic Jurisprudence, disclosing others' sins is considered haram. Regarding the mentioned verse, Imam Sadeq says: "those who quote what they have seen or heard about the believers, are those God has talked about in this way" (Najafi, 1989, 357). The relation between prohibition of prostitution and violation of privacy is an interesting one not only in terms of personal aspect, but also in terms of public aspect. Personal propagation of prostitution results in violation of privacies, and disclosure of their flaws.

Propagating prostitution is very important since it also covers the other instances of violation of privacy. However, if any of the instances of violation of privacy such as making accusations or backbiting exceed the limits of the personal privacy and cause propagation of prostitution, the issue becomes an issue of public importance, and the consent of the subject also will not be effective on relieving the sentence. In other words, propagating prostitution may criminalize any of the instances of violation of privacy, making it virtually possible to legally prosecute the offender.

\section{Prohibition of Eavesdropping}

Eavesdropping is an important instance of investigation, and is dealt with separately. In general eavesdropping occurs when someone listens to another one with their consent, or watches them secretly. This act is considered as haram in Sharia of Islam, and someone who secretly controls or monitors others' communications, has committed the crime of investigating others' privacy. Prophet Muhammad interprets eavesdropping as: each part of the human body can participate in adultery, and for the ears, the adultery is secretly listening to others (Noorbahar 1990). In addition, Prophet Muhammad says: when someone listens to others without their consent, will have his ears filled with melted lead in the afterlife (Noorbahar 1990). 
In addition, visual eavesdropping is also defined as unapproved looking to anything that is located in others' privacy. The subject of the privacy is not okay with having it seen by others, and that's why it has been kept out of sights. In Islamic Jurisprudence humans have been recommended to avoid providing the necessary contexts for violation of privacy by looking. In the verse 19 of sura of Fater, the Quran says:

in this verse, the betrayal of the eyes is exemplified as unauthorized looking at communications of people. Regarding unauthorized looking at people's communications, Prophet Muhammad says: if someone takes an unauthorized look at his brother's letter, it would be as if he/she has looked at their genitals. In addition, this narrative can be pointed to as well (Al-Khasal, 1990).

Jurists believe that looking at non-mahram (women with whom you aren't married, or can’t marry them at all) is haram, and also peeking at others' homes and houses is also considered illegitimate. Even if someone looks at the inside of others' homes and houses from distant, using tools such as binoculars, it is still a haram act (Muhaddith, 1990). According to sentences of Sharia of Islam, if someone causes another to lose the sight of both eyes, the offender is urged to pay a whole man's blood money; also, the blood money for one eye is equal to half the whole blood money for a man. But if someone is secretly peeking at homes or families of people and gets hurt while doing so, even if the eyes are hurt, no blood money will be paid. This sentence show that betraying eyes have no value, at the same time stressing out the importance of the privacy, and that violating it is prohibited in the eyes of Islamic jurisprudence. In an answer to this question: what is the sentence for unauthorized eavesdropping using eavesdropping apparatuses to record the communications of people, which they tend not to disclose? Some jurists believe that if not necessary for greater good reasons for the interest of the public, it is not desirable and legitimate to do so. By considering eavesdropping as haram, Islam block certain ways of violating the privacy; however, according to several jurisprudential sentences, this sentence is generalizable to affairs related to the cyberspace as well. In addition, from certain points of views, it can be stated that this sentence is even more inclusive in cyberspace.

\section{Conclusion}

Through the conducted investigations, it is made clear that certain crimes that have used the social media to diminish chastity in the society include disclosure of adultery, pandering, 
pornography and etc. which have been referred to by legislators and the holy Imams and Prophet. In the first step, not only these crimes are against the offender, but also target and weaken the bases of every society’s most important units, which are the families. By prevention through a variety of solutions such as training, educating, and controlling, a great deal of help is offered to fortify the families' bases. In addition, by exercising better control and supervision on the children and adolescents, the families can prevent such crimes and save their children from such traps.

By relying on the principal inferences of jurisprudence, the present study has extracted certain components in support of privacy, and in this regard it has been shown that: Five main principles of Islam to provide a general support for privacy include the formerly mentioned sevenfold components of prohibition of investigation, and spying; prohibition of suspicion; prohibition of insulting; prohibition of backbiting; prohibition of malversation; prohibition of eavesdropping; and, prohibition of propagation of prostitution; the Quran introduces the best and most irreplaceable ways to prevent social crimes and corruption. All of these methods are an integral part of comprehensive prevention policy. To fulfill its main mission, the Qur'an places special emphasis on the moral reform and training of individuals and the delivery of human beings to high spiritual authorities. In addition to leading man to the ultimate perfection and nearness to God, this can effectively prevent the commission of crimes.

\section{References}

Al-Khasal, Q. (1990). Al-Khasal. Qom Teachers Association publisher. https://ketabeqom.com/publisherinfo/151.

Ameli Zayn al-Din bin A., Al-Rawdha, A. (2008). Al-Bahiyya in the explanation of Friday. translated by Hamid Masjid Sarai, Qom, Islamic Law Publications, second edition. https://www.ketabcity.com/BookList.aspx?Type=PubRefid\&Code=47945

Azad Fallah, R. (2008). Computer Crimes. Master Thesis, Azad University, Tehran Branch, by Research Sciences Branch publisher. http://pazhooheshi.srbiau.ac.ir/fa

Bai, H. A., Poor Ghahraman, Babak. (2016). Jurisprudential Legal Study of Computer Crimes. Qom, Institute of Islamic Sciences and Culture, first edition. http://www.isca.ac.ir/Portal/Home/

Bastani, B. (2018). Computer Crimes. New Manifestations of Delinquency, Tehran, Behnami Publications, First Edition. https://www.kikojas.com/place

Ghodsi, Z., Abolhassan Mojtahed, S. (2010). Computer crimes against morality and chastity in the privacy of the family, especially the crime of prostitution and pornography. Nedaye Sadegh Quarterly, 53(3), 35-56. http://flj.journals.isu.ac.ir/article_39985.html 
Haji, D., Mohammad ,Ali. (2001). Crime Prevention, in: Imam Ali (AS) Encyclopedia. Tehran, Institute of Islamic Culture and Thought publisher. http://iict.ac.ir/

Ismaili, M., Nasrollahi, M. (2016). Cyberspace Refining; Rulings and its issues from the jurisprudential point of view. religion and communication. 21(1), 60-57. http://rc.journals.isu.ac.ir/article_1875.html

Keshavarzi, A. (2014). Islamic Penal Code, Tehran, Jangal publisher, p. 482. https://jangal.com/

Khorasani, A. (2002). International tool for crime, Jam Jam publisher, Tehran. https://jjp.ir/

Makarem Shirazi, N. (1995). Sample Interpretation. Tehran, Islamic Library publisher. http://www.nlai.ir/publishers

Maki, M. (2007). Al-Rawdha al-Bahiyya in the explanation of Friday. translated and explained by Ali Shirvani, Qom, Dar al-Fikr Publications, thirty-second edition, summer.

Mir Khalili, Mahmoud. (2001). Situational prevention from the perspective of the teachings of Islam. jurisprudence law, and 45-66. http://hoquq.iict.ac.ir/article_22640_350ea6b4b6e1d8893cc320bdd63bbc3b.pdf

Mohammad, H. (2004). Computer Crimes, Management and Planning Organization, Secretariat of the Supreme. Informatics Council, 36-44. http://www.nexusacademicpublishers.com/uploads/portals/Cyber_Security_Challenged_ Ahead.pdf

Muhaddith, N., Mirza, H. (1990). Mustadrak al-Wasa'il wa Mustanbat al-Masa'il. Beirut. Al-Bayt Institute publisher. https://www.aalalbayt.org/other-publications/

Najafi, M. H. (1989). Jawahar al-Kalam in the explanation of Islamic law. Qom, Islamic Library publisher.

Noorbahar, R. (1990). Field of Public Criminal Law. Tehran, Bar Association Publishing Center. http://icbar.ir/

Saffari, Ali. (2001). Theoretical Foundations of Crime Prevention. Legal Research, 33(3), 49-55. http://ensani.ir/fa/article/7151 